\title{
A dizájner drog metiléndioxi-pirovaleron hatása a fejlődő idegrendszerre kísérletes állatmodellben
}

\author{
Gerecsei László István oh. - Ádám Ágota dr. \\ Semmelweis Egyetem, Anatómiai, Szövet- és Fejlődéstani Intézet, Budapest
}

\begin{abstract}
Bevezetés: A szintetikus kationok családjába tartozó „dizájner drog”, a metiléndioxi-pirovaleron gyakran használt pszichoaktív szer. Célkitúzés: A szerzők arra a kérdésre kerestek választ, hogyan hat a metiléndioxi-pirovaleron a vemhesség 8. és 14. napja között adva az utódegerek központi idegrendszerének fejlődésére és a viselkedésükre. Módszer: Nőstény egereket a vemhesség ezen időszakában $1 \times 10 \mathrm{mg} / \mathrm{ttkg}$ metiléndioxi-pirovaleron-oldattal kezeltek subcutan, a kontrollcsoport fiziológiás sóoldatot kapott. Mérték az anyaállatok utódgondozási hajlandóságát, lokomotoros aktivitását és motoros koordinációját. Az utódokon a postnatalis 7. és 21. napon ugyanezeket a teszteket végezték el. Eredmények: Az anyaállatok utódgondozási hajlandósága csökkent. A lokomotoros aktivitási tesztben nem volt különbség a krónikusan kezelt állatok és a kontrollcsoport között. A motoros koordinációs teszt eredményei alapján a krónikusan kezelt állatok motoros koordinációja rosszabb volt. A metiléndioxi-pirovaleronnal krónikusan kezelt utódoknál a lokomotoros aktivitás csökkent. Következtetések: Az eredmények arra utalnak, hogy a metiléndioxi-pirovaleron hátrányosan befolyásolja a központi idegrendszer neuronjainak integritását.
\end{abstract}

Orv. Hetil., 2015, 156(30), 1221-1225.

Kulcsszavak: dizájner drog, 3,4-metiléndioxi-pirovaleron, viselkedés, terhesség, teratogenitás

\section{Effects of the designer drug methylenedioxypyrovalerone on the developing brain in experimental animal model}

Introduction: The designer drug methylenedioxypyrovalerone is a frequently used psychoactive drug of abuse. Aim: The aim of this study was to determine the effect of methylenedioxypyrovalerone, administrated from the 8 th to the 14th day of the gestation, on the development of central nervous system and on the behaviour of offspring mice. Method: Pregnant mice were treated during this period either with subcutaneous injection of $1 \times 10 \mathrm{mg} / \mathrm{kg}$ body weight methylenedioxypyrovalerone or vehicle (saline). Maternal behaviour (pup retrieval test), locomotor activity (open field test) and motor coordination (grip strength test) of dams were evaluated. Locomotor activity at the 7 th and 21 st postnatal day (open field test) and motor coordination at the 21 st postnatal day (grip strength test) were examined. Results: Reduced maternal behaviour among treated animals was observed. There was no difference in the results of the open field test between treated and control groups. Decrease of locomotor activity was observed in the pups of the methylenedioxypyrovalerone treated dams. Conclusions: The results suggest that cathinones (in particular methylenedioxypyrovalerone) may adversely affect neural integrity of the developing central nervous system.

Keywords: designer drug, 3,4-methylenedioxypyrovalerone, behaviour, pregnancy, teratogens

Gerecsei, L. I., Ádám, Á. [Effects of the designer drug methylenedioxypyrovalerone on the developing brain in experimental animal model]. Orv. Hetil., 2015, 156(30), 1221-1225.

A Dr. Fehér János Alapítvány 2015. évi pályázatán díjat nyert dolgozat.

(Beérkezett: 2015. április 23.; elfogadva: 2015. május 28.) 
2010 óta a Magyarországon lefoglalt drogok között az úgynevezett „dizájner drogok” aránya folyamatosan emelkedik. A Nemzeti Drog Fókuszpont éves jelentése szerint 2013-ban a droglefoglalások 49\%-a csak ilyen típusú szert tartalmazott [1]. A dizájner drogok olyan ismert és illegális pszichoaktív szerek strukturális és funkcionális analógjai, amelyek utánozzák az eredeti szer farmakológiai hatását, azonban törvényi korlátozás alatt nem állnak és/vagy az általánosan használt eljárásokkal nehezen detektálhatóak [2]. Hatásuk az anyavegyülettől függően lehet kannabisszerü, stimuláns, hallucinogén vagy pszichedelikus. Terjedésükhöz nagyban hozzájárul az internet, a viszonylag alacsony ár és a használó azon hite, hogy az alkalmazott szer legális [3]. Számos internetes oldalon „növényvédő szerként” vagy „fürdősóként” árusítják ezeket a vegyületeket. A növekvő elterjedtség ellenére e szerek krónikus hatásai, fóleg azok, amelyek a fejlődő szervezetre irányulnak, kevéssé ismertek, pedig terhes nők is előfordulhatnak fogyasztóik között. A budapesti székhelyű Józan Babák Klub alternatív terhességgondozó szervezet felmérése szerint az utóbbi években a rendszeresen szerhasználó kismamák körében a vényköteles gyógyszerek és az alkohol mellett a dizájner drogok használata a leggyakoribb, jelentősen megelőzve a magzatra napjainkra már jóval ismertebb hatással bíró opiátokat, kokaint és amfetamint. Ezen új szerek kísérletes vizsgálata rendkívül időszerű és nagy jelentőséggel bír.

E „fürdősók” egyik legelterjedtebb összetevője a 3,4-metilén-dioxi-pirovaleron (MDPV) [4]. Az MDPV a szintetikus katinonok egyike; e vegyületcsoport tagjai kémiailag a fóleg Afrikában és az Arab-félszigeten honos kát növény (Catha edulis) hatóanyagából, a katinon- ból származtathatók [5]. Az MDPV emberre gyakorolt akut hatásai közé tartozik a tachycardia, vérnyomásemelkedés, izzadás, eufória, megnövekedett éberség, ingerlékenység és szociabilitás, valamint csökkent étvágy és alvásigény. Ezekért a hatásokért az MDPV központi idegrendszerben kifejtett noradrenalin- és dopaminviszszavétel-gátló hatása felelős, de - ellentétben az egyébként igen hasonló amfetaminnal - az MDPV nem indukál monoamin-felszabadulást a szinapszisban [6]. Az elsődleges pszichológiai hatások 3-4 órán át tartanak. A használat módjai igen változatosak: általában per os, de előfordul inhalációs, rectalis, illetve intravénás bevitel is [6].

Jelen kutatásunkban az MDPV fejlődő idegrendszerre gyakorolt hatásait kívántuk tanulmányozni egérmodellen.

Korábbi kutatásaink igazolták, hogy már egyetlen adag MDPV is képes apoptózist kiváltani 7 napos egerek bizonyos agyterületein [7]. Ismert, hogy egérben a postnatalis 4-10. nap megfeleltethető a humán terhesség 3. trimeszterének az idegrendszer fejlődése szempontjából, és ebben az időszakban az idegsejtek száma jelentősen növekszik [8]. A C57BI/6J törzshöz tartozó egereknek $10 \mathrm{mg} /$ ttkg MDPV-t adagoltunk intraperitonealisan fiziológiás sóoldatban oldva (a kontrollállatok csak vehiculumot kaptak) a postnatalis 7. napon. Ezt követően, 24 óra elteltével, az állatokat szöveti fixálás céljából túlaltattuk, majd 4\%-os pufferelt paraformaldehidoldattal transcardialisan perfundáltuk. Az eltávolított agyakból fagyasztott metszeteket készítettünk, majd kaszpáz-3 elleni antisavóval immunhisztokémiai festést végeztünk. A kaszpáz-3 fehérje kulcsszerepet játszik az apoptózis végső szakaszában, egyike az úgynevezett ef-

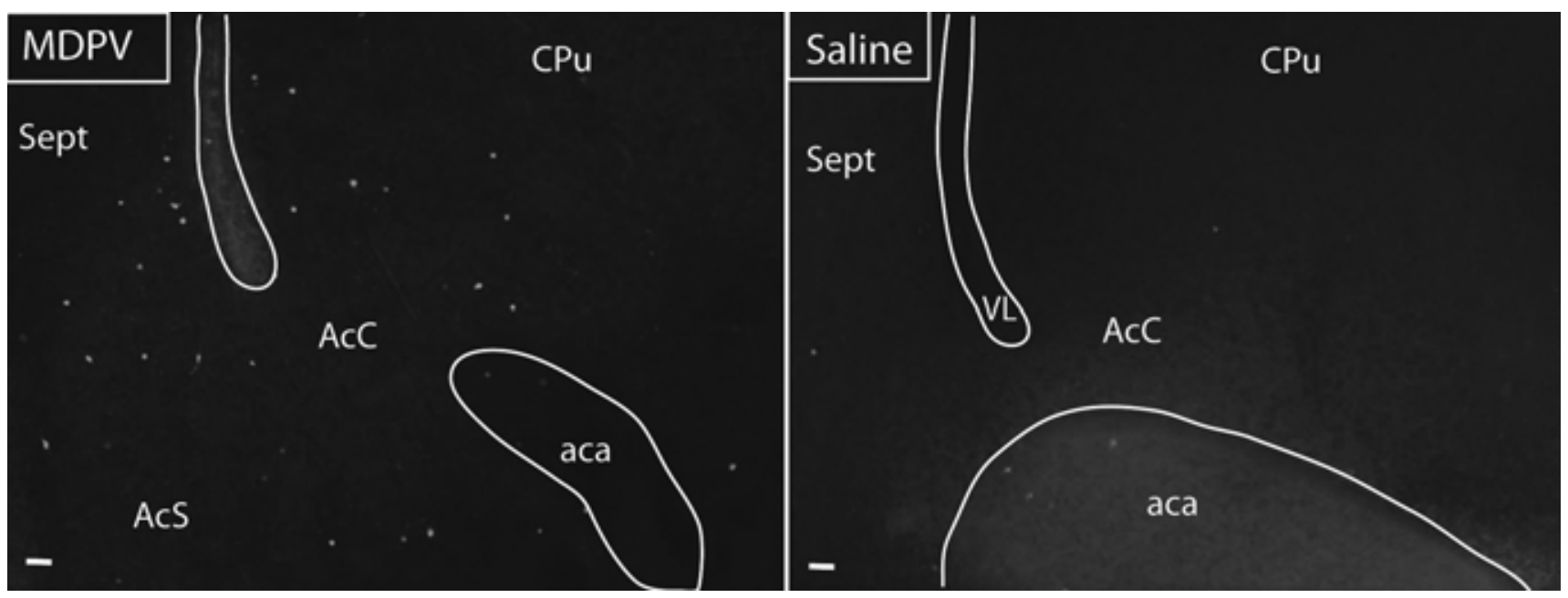

1. ábra $\quad$ Anti-kaszpáz-3 immunhisztokémia frontális irányú agyi metszeteken a nucleus accumbens core (AcC) és schell (AcS) régióiban intraperitonealis MDPV (bal oldalon) vagy fiziológiás sóoldat (jobb oldalon) adagolását követően 7 napos egérben. Látható a kaszpáz-3-pozitív sejtek jelentősen nagyobb száma az MDPV-vel kezelt állatok nucleus accumbensében, amely alapján valószínúsíthető, hogy az MDPV-kezelés következtében ezen az agyterületen apoptózis következett be

$\mathrm{aca}=$ comissura anterior, $\mathrm{CPu}=$ caudate-putamen; $\mathrm{Sept}=$ septum; $\mathrm{VL}=$ oldalkamra. Lépték: $50 \mu \mathrm{m}$

(Forrás: Ádám, Á., Gerecsei, L. I., Lepesi, et al., Neurotoxicology, 2014 [7] - az Elsevier kiadó engedélyével) 
fektor kaszpázoknak, amelyek a sejt fehérjéinek proteolízisére képesek [9]. Eredményeink azt mutatták, hogy a kezelt állatokban szignifikánsan több apoptotikus sejt található a nucleus accumbensben (1. ábra), a retrosplenialis areában, a hippocampus CAl régiójában és a piriform kéregben [7], vagyis a hatás olyan limbikus agyi területekre összpontosul, amelyek ismert szerepet játszanak az érzelmi válaszokban, a motivációban, a tanulásban és az addikcióban. Kisebb mértékü apoptózis az egész (motoros funkciót képviselő) striatum területén is megfigyelhető volt.

Mindezek alapján felmerült a kérdés, hogy hogyan hat a vemhesség alatt adagolt MDPV az utódegerek viselkedésére, illetve hogyan hat magukra az anyaállatokra. Jelen dolgozat ezen kérdéssel foglalkozó vizsgálatunk eddigi eredményeit mutatja be.

\section{Módszer}

Kezelés

Kutatásunk során 20 darab C57BL/6J törzsbeli nőstény vemhes egeret használtunk fel, amelyek krónikus kezelés során naponta $1 \times 10 \mathrm{mg} /$ ttkg MDPV-oldatot kaptak subcutan injekcióban a vemhesség 8 . és 14. napja között. Ez az időszak az agyfejlődés szempontjából a humán terhesség első trimesztere második felének feleltethető meg (a terhesség 8-12. hete). Azért választottuk ezt a periódust, mert ebben az időszakban alakulnak ki a striatum dopaminerg neuronjai. A kontrollállatok fiziológiás sóoldatot (vehiculum) kaptak ugyanilyen módon és ideig.

Akut drogkezelés esetén az anyaállatok $1 \times 10 \mathrm{mg} / \mathrm{ttkg}$ MDPV-t (a kontrollállatok vehiculumot) kaptak subcutan, majd 10-30 perc múlva végeztük a viselkedési teszteket.

A kutatást az Egészségügyi Engedélyeztetési és Közigazgatási Hivatal (ez év március 1-jétől Egészségügyi Nyilvántartási és Képzési Központ) Kábítószerügyi Főosztályának engedélyével (27924/2011/KÁB) végeztük. A kísérlethez használt MDPV-t a gyártótól (LGC Standards, Teddington, Middlesex, UK), a fóti székhelyű Medinspect Kft. közremúködésével szereztük be.

\section{Viselkedési tesztek}

Fészekbe hordási teszt (úgynevezett pup retrieval test). Az anyaállatokon végzett vizsgálat, amellyel az utódgondozási hajlandóság mértékére következtethetünk [10]. A teszt arra alapul, hogy az anyaállat utódai számára kijelöl egy fészket, és ha a fészekből az utódokat a ketrec egy másik pontjára helyezzük át, akkor az anyaállat viszszaviszi oda azokat. Mértük, hogy az anyaállat hány másodperc után kezd hozzá a fészekből eltávolított utódok begyưjtéséhez, illetve hány másodperc elteltével végez az utolsó utód fészekbe vitelével.

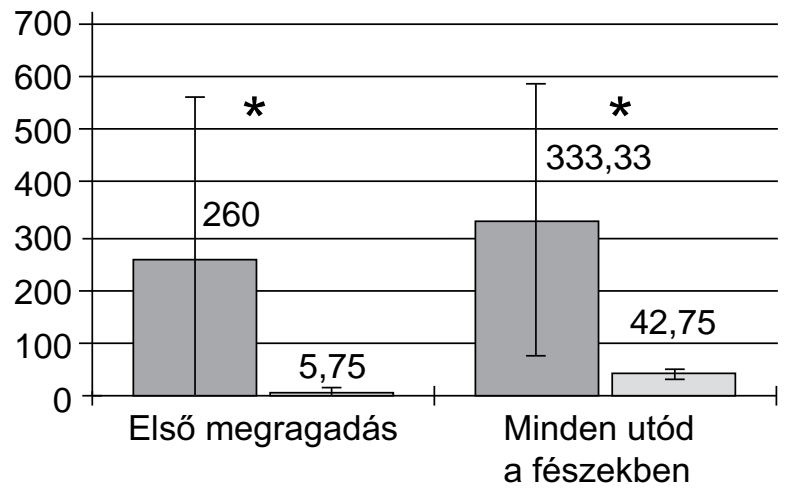

Kezelt $(n=3) \quad \square$ Kontroll $(n=4)$

2. ábra $\quad$ A vemhesség alatt krónikusan MDPV-vel kezelt anyaállatok fészekbe hordási (pup retrieval) tesztjének eredményei. Függöleges tengely: idő (s). Mind az első utód megragadása, mind az utolsó utód fészekbe vitele több idő elteltével történt meg a vemhesség alatt MDPV-vel kezelt állatok esetén, azaz a drogkezelés csökkentette az utódgondozási hajlandóságot

*Mann-Whitney U-teszt, $\mathrm{p}<0,05$

Kapaszkodási teszt (úgynevezett grip strength test). Az anyaállatokon, illetve 21 napos utódaikon végeztük ezt a vizsgálatot, amelynek lényege, hogy egy zárt térrész (aréna) fölé vízszintesen fémrudat feszítünk ki, majd mérjük, hogy a ráhelyezett állat hány másodpercig képes a fémrúdon megkapaszkodni, avagy mennyi idő után esik le. A teszt alkalmas a motoros koordináció vizsgálatára [11].

Aréna-teszt (open-field test). Ezt a vizsgálatot az anyaállatokon és 7, illetve 21 napos utódaikon végeztük. Ennek során a kísérleti állatot egy zárt térrészbe (aréna) helyeztük, amelynek az aljára előzetesen négyzetes rácsozatot rajzoltunk, majd feljegyeztük, hogy 5 perc alatt hányszor keresztezi az állat a rácsvonalakat [12].

\section{Eredmények}

$\mathrm{Az}$ anyaállatok fészekbe hordási tesztje azt mutatta (2. ábra), hogy a vemhesség alatt krónikusan kezelt állatoknak átlagosan 260,0 másodpercig tartott az első utód megtalálása és megragadása, míg a kontrollcsoportnak ehhez szignifikánsan rövidebb idő, 5,75 másodperc kellett. Hasonlóképpen, szignifikánsan hosszabb ideig tartott az utolsó utód begyüjtése a kezelt csoportnak ( $\mathrm{t}=$ $333,3 \mathrm{~s})$, mint a kontrollcsoport állatainak $(\mathrm{t}=42,75 \mathrm{~s})$.

$\mathrm{Az}$ anyaállatok kapaszkodási tesztjének eredményét elemezve feltúnik, hogy a vemhesség alatt alkalmazott kezelés rontja a teljesítményt; ezen állatok átlagosan mintegy feleannyi ideig $(\mathrm{t}=6,67 \mathrm{~s})$ voltak képesek a kifeszített fémrúdon fennmaradni, mint kontrolltársaik $(\mathrm{t}=14,47 \mathrm{~s})$ (3. ábra).

Egyszeri MDPV-dózis akut hatására mind a krónikusan kezelt, mind a kontrollcsoport tagjai jobban teljesítettek, vagyis hosszabb ideig voltak képesek a kifeszí- 


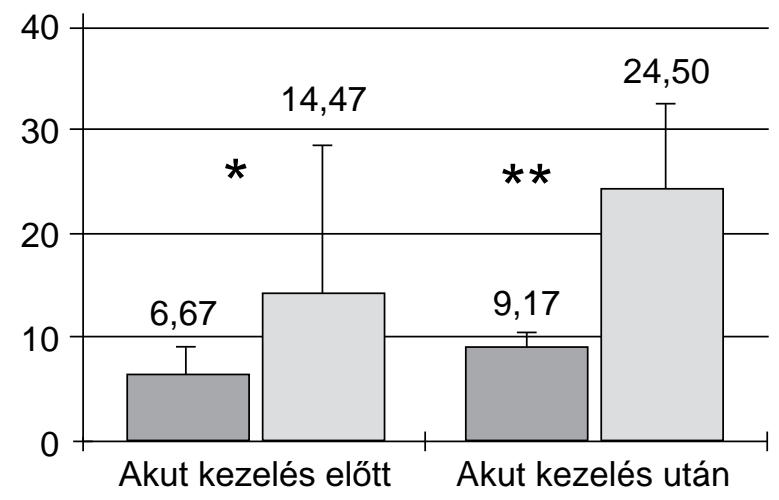

Kezelt anyaállatok $(\mathrm{n}=6)$

$\square$ Kontroll anyaállatok $(n=10)$

3. ábra
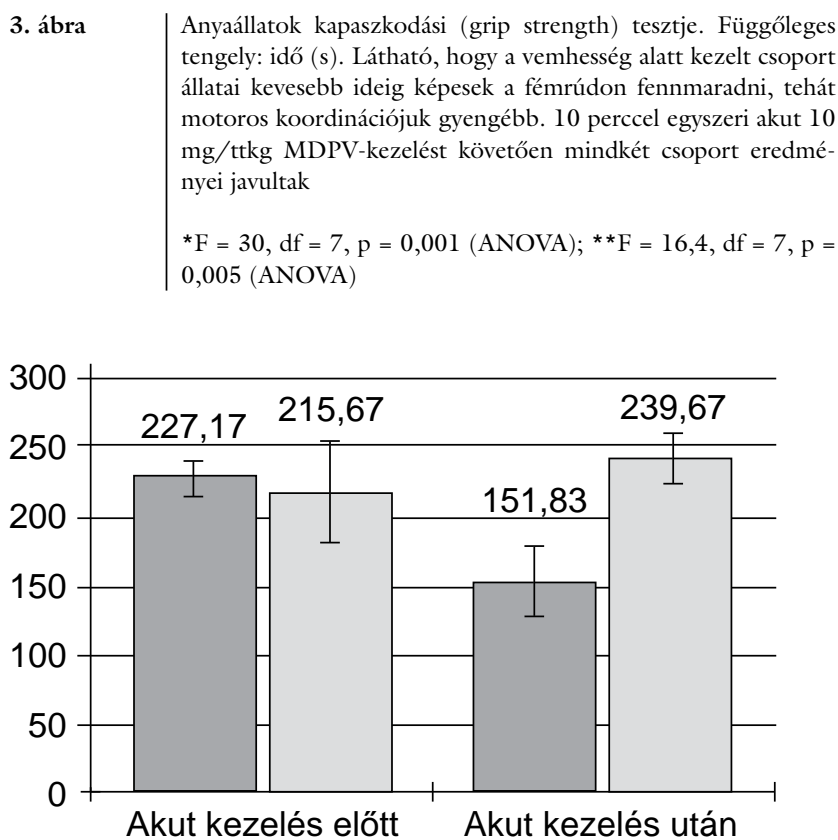

Kezelt anyaállatok $(\mathrm{n}=6)$

$\square$ Kontroll anyaállatok $(n=3)$

4. ábra Anyaállatok aréna- (open-field) tesztje. Függőleges tengely:
rácsvonal-keresztezések száma. A vemhesség alatt kezelt és a
kontrollállatok eredménye között nincs kimutatható különb-
ség. Egyszeri akut $10 \mathrm{mg} /$ ttkg MDPV hatására a korábban ke-
zelt állatok lokomotoros aktivitása csökken, míg a kontrollálla-
tok lokomotoros aktivitása növekszik. Ez statisztikailag azonban
csak trendszerúen állapítható meg
$\mathrm{t}=2,3, \mathrm{n}=9, \mathrm{p}=0,057$ (kétmintás t-próba)

tett fémrúdon kapaszkodni a kapaszkodási teszt során (3. ábra).

Az anyaállatokban elvégzett aréna-teszt tanúsága szerint, a vemhesség alatt kezelt és a kontrollcsoport tagjainak eredménye között nincs különbség, azonban a már előbb említett egyszeri akut MDPV-kezelés eltérően hat a két csoportra. Míg a kezelt csoport tagjainak motoros aktivitása csökkent, addig a kontrollcsoport eredménye

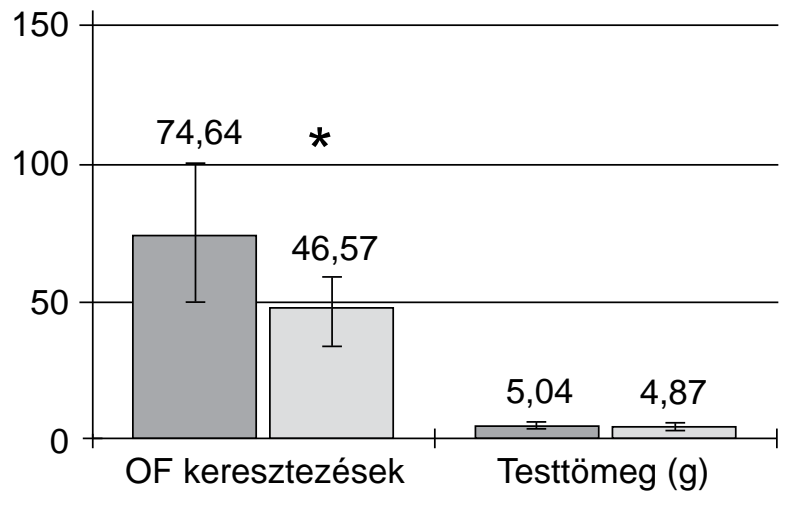

Kezelt $(\mathrm{n}=14) \quad \square$ Kontroll $(\mathrm{n}=7)$

5. ábra $\mid 7$ napos egerek aréna-tesztjének eredményei. Függőleges tengely: rácsvonal-keresztezések száma, illetve testtömeg $(\mathrm{g})$. A kezelt állatok aréna-tesztjének eredménye szerint a lokomotoros aktivitásuk szignifikánsan magasabb a kontrollállatokénál ( ${ }^{*} \mathrm{p}=$ 0,014; Mann-Whitney U-teszt). A testtömegben nincs jelentős különbség

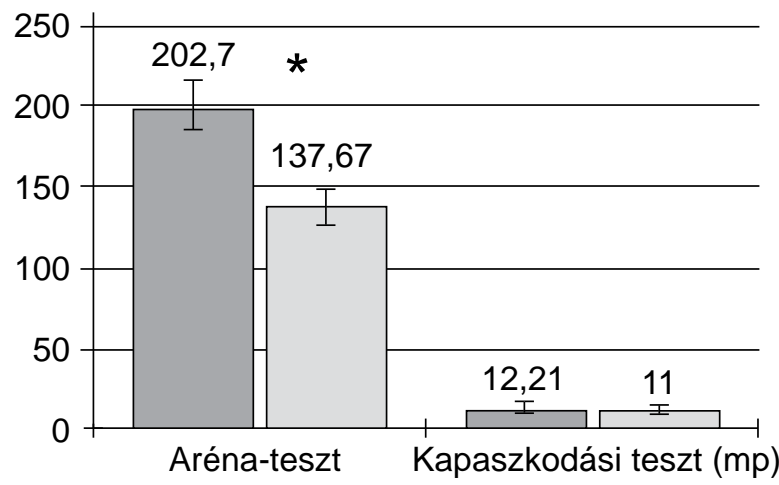

$\square$ Kezelt $(n=13) \quad \square$ Kontroll $(n=6)$

\begin{tabular}{l|l} 
6. ábra & 21 napos utódok aréna- és kapaszkodási tesztjeinek eredmé-
\end{tabular} nyei. Függőleges tengely: rácsvonal-keresztezések száma, illetve idő (s). Hasonlóan a 7 napos utódokhoz, a terhesség alatt krónikusan kezelt anyák utódainak lokomotoros aktivitása nagyobb; ezek többször keresztezték az aréna rácsozását ( ${ }^{*} \mathrm{p}=$ 0,014; Mann-Whitney U-teszt). A kapaszkodási teszt eredményében azonban nem volt jelentős eltérés a csoportok között

éppen ellentétes irányú változást mutatott (4. ábra). Ez azonban statisztikailag legfeljebb trendszerúen állapítható meg.

Az utódokat vizsgálva megfigyeltük, hogy 7 napos korban azok az állatok, amelyek anyja vemhesség alatt MDPV-t kapott, az aréna-teszt során nagyobb aktivitást mutattak, mint a kontrollanyák utódai. A mért testtömegben nem volt különbség a csoportok között (5. ábra).

Két héttel később, 21 naposan is elvégeztük az utódegerekkel az aréna-tesztet, és - hasonlóan a 7 napos korban vizsgáltakhoz - azt láttuk, hogy a vemhesség alatt krónikusan kezelt anyák utódai nagyobb aktivitást mutatnak a teszt során, mint a kontrollállatok utódai (6. ábra). Ebben az életkorban már a kapaszkodási teszt 
is elvégezhető, azonban ebben nem találtunk eltérést a két csoport eredményei között.

\section{Megbeszélés}

Eredményeinket összefoglalva elmondhatjuk, hogy a vemhesség alatt krónikusan adagolt MDPV csökkenti az anyaállatok utódgondozási hajlandóságát. Ugyancsak az anyaállatokban figyeltük meg azt is, hogy bár a mozgási aktivitás nem módosul krónikus MDPV-kezelés hatására, a későbbi egyszeri kezelésre adott akut választ a korábbi krónikus kezelés módosíthatja. Az aréna-teszt során azonban azt is észleltük, hogy akut MDPV hatására gyakoribbá váltak az embernél is ismert úgynevezett sztereotip viselkedésformák: ez egerek esetén rágcsálást, kényszeresnek tünő mosakodást, a fej különböző irányokba való biccentését jelenti. A sztereotipikus mozgások csökkenthetik a helyváltoztatás mértékét, ami az aréna-teszteknél nem kívánt befolyásoló tényezőként (mintegy zajként) léphet fel. Az MDPV krónikus adagolása csökkenti az anyaállatok motoros koordinációs képességét, ezt a kezelt csoportban 'rosszabb' kapaszkodási teszteredmények alapján mondhatjuk ki. Ez összhangban van korábbi eredményeinkkel, amelyek a striatumnak az MDPV hatására kialakuló károsodását mutatták [7].

Az utódegerek esetében megállapítottuk, hogy mind a postnatalis 7., mind a 21. napon mérve, az MDPV-vel kezelt állatok utódai nagyobb motoros aktivitást mutattak, mint a kontrollállatok utódai. Ennek egyik oka lehet a csökkent anyai törődés, ugyanis a fészekbe hordási tesztek eredményei alapján valószínúsíthető, hogy ezeknek a kisegereknek többet kell tenniük az anyai gondoskodásért, élelemért, mint a kontrollállatok utódainak. Egy másik lehetséges, de egyelőre bizonyításra szoruló magyarázat azt feltételezi, hogy az anyaállat krónikus drogexpozíciója hatására az utódok in utero olyan agyi változásokat szenvednek el, amelyek a motoros és/vagy motivációs rendszert tartósan károsítják. Az utóbbi eshetóség - éppen a humán analógiák miatt elég aggasztó ahhoz, hogy a téma további kísérletes vizsgálatát az eddigi és továbbfejlesztett vizsgálati módszerek segítségével megalapozza.
Anyagi támogatás: Jelen kutatás az OTKA PD-105251-es számú pályázatának támogatásával valósult meg.

Szerzői munkamegosztás: A szerzők a munka összes fázisában egyenlő arányban vettek részt. A cikk végleges változatát mindkét szerző elolvasta és jóváhagyta.

Érdekeltségek: A szerzőknek nincsenek érdekeltségeik.

\section{Irodalom}

[1] 2014 National Report (2013 data) to the EMCDDA by the Reitox National Focal Point. [2014-es éves jelentés (2013-as adatok) az EMCDDA számára. Készítette: Nemzeti Drog Fókuszpont.] www.drogfokuszpont.hu [Hungarian]

[2] Woblfarth, A., Weinmann, W.: Bioanalysis of new designer drugs. Bioanalysis, 2010, 2(5), 965-979.

[3] Szily, E., Bitter, I.: Designer drugs in psychiatric practice - A review of the literature and the recent situation in Hungary. Neuropsychopharmacol. Hung., 2013, 15(4), 223-231.

[4] Spiller, H. A., Ryan, M. L., Weston, R. G., et al.: Clinical experience with and analytical confirmation of "bath salts" and „legal highs" (synthetic cathinones) in the United States. Clin. Toxicol. (Phila.), 2011, 49(6), 499-505.

[5] Coppola, M., Mondola, R.: Synthetic cathinones: Chemistry, pharmacology and toxicology of a new class of designer drugs of abuse marketed as "bath salts" or "plant food". Toxicol. Lett., 2012, 211(2), 144-149.

[6] Miotto, K., Striebel, J., Cho, A. K., et al.: Clinical and pharmacological aspects of bath salt use: a review of the literature and case reports. Drug Alcohol Depend., 2013, 132(1-2), 1-12.

[7] Ádám, Á., Gerecsei, L. I., Lepesi, N., et al.: Apoptotic effects of the 'designer drug' methylenedioxypyrovalerone (MDPV) on the neonatal mouse brain. Neurotoxicology, 2014, 44, 231-236.

[8] Bayer, S. A., Altman, J., Russo, R. J., et al.: Timetables of neurogenesis in the human brain based on experimentally determined patterns in the rat. Neurotoxicology, 1993, 14(1), 83-144.

[9] Porter, A. G., Jänicke, R. U.: Emerging roles of caspase-3 in apoptosis. Cell Death Differ., 1999, 6(2), 99-104.

[10] Porter, R. H.: Communication in rodents: adults to infants. In: Elwood, R. W. (ed.): Parental behaviour of rodents. John Wiley \& Sons Ltd., Chichester, 1983.

[11] Crabbe, J. C., Cotnam, C. J., Cameron, A. J., et al.: Strain differences in three measures of ethanol intoxication in mice: the screen, dowel and grip strength tests. Genes Brain Behav., 2003, 2(4), 201-213.

[12] Walsh, R. N., Cummins, R. A.: The open-field test: a critical review. Psychol. Bull., 1976, 83(3), 482-504.

(Ádám Ágota dr., Budapest, Tûzoltó u. 58., 1094 e-mail: agota@ana.sote.hu) 